\title{
Expanded Central Nervous System Gene Transfer in Rats by Intravenous Delivery of Recombinant Adeno-Associated Virus
}

Kasey L. Jackson ${ }^{1 *}$, Blas S. Catalani ${ }^{2}$, Robert D. Dayton ${ }^{1}$ and Ronald L. Klein ${ }^{1}$

${ }^{1}$ Department of Pharmacology, Toxicology, and Neuroscience, Louisiana State University Health Sciences Center, Shreveport, LA 71130, USA

${ }^{2}$ Department of Anesthesiology, Louisiana State University Health Sciences Center, Shreveport, LA 71130, USA

"Corresponding author: Kasey L. Jackson, Department of Pharmacology, Toxicology, and Neuroscience, Louisiana State University Health Sciences Center, Shreveport, LA 71130, USA, Tel: 2255783202; E-mail: kaseylsuhsc@gmail.com

Rec date: Nov 10, 2014, Acc date: Nov 12, 2014, Pub date: Nov 14, 2014

Copyright: (c) 2014 Jackson KL, et al. This is an open-access article distributed under the terms of the Creative Commons Attribution License, which permits unrestricted use, distribution, and reproduction in any medium, provided the original author and source are credited.

\section{Description}

Viral vector gene transfer is an important tool for studying protein function in vivo. Recombinant adeno-associated virus (AAV) is advantageous for gene transfer to the central nervous system. Over the past few years it has been shown that an intravenous vector delivery can transduce neurons throughout the central nervous system [1-3]. The images are of rats administered AAV serotype 9 vector encoding green fluorescent protein (GFP). The rats were injected intravenously on post-natal day one and imaged for GFP expression 4-12 weeks later. There is robust expression in the spinal cord and dorsal root ganglia and the cerebellum (Figures 1-3). We have been exploiting the efficient spinal cord transduction to study a spinal cord disease, amyotrophic lateral sclerosis [2-4].

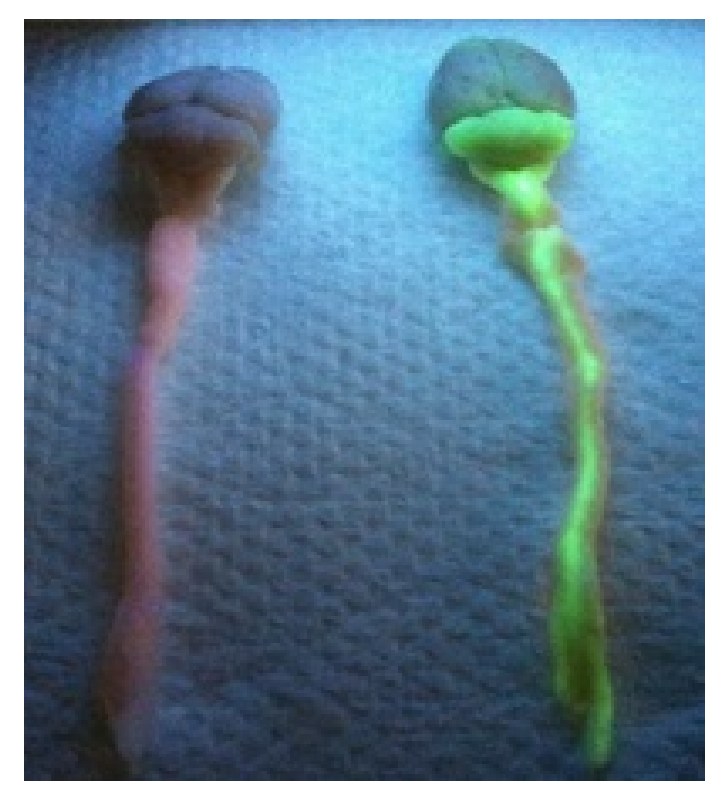

Figure 1: GFP expression in the rat spinal cord and cerebellum on the right, visualized with an ultraviolet lamp. A control sample is on the left.

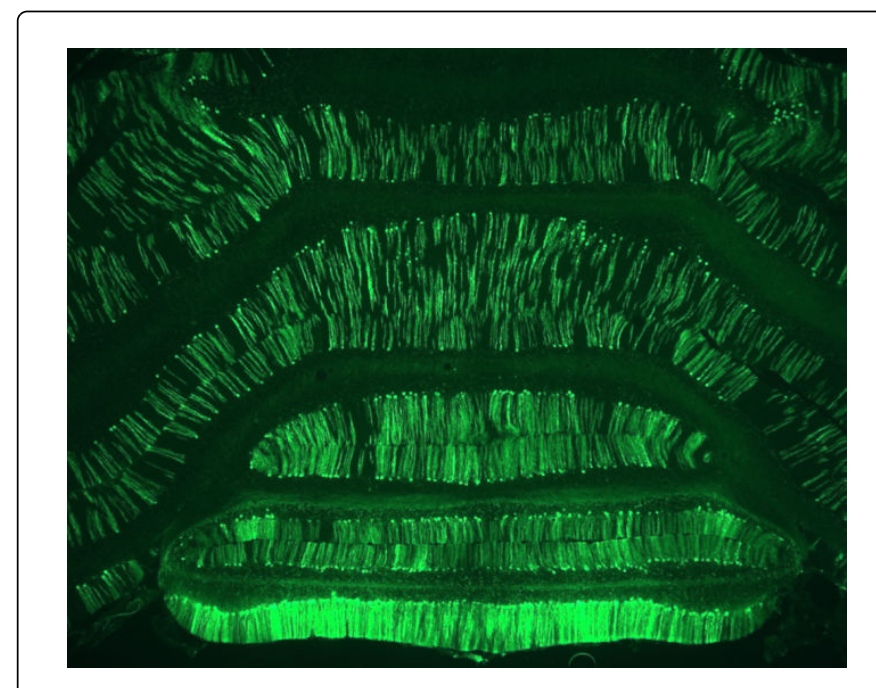

Figure 2: GFP expression in rat cerebellar Purkinje neurons.

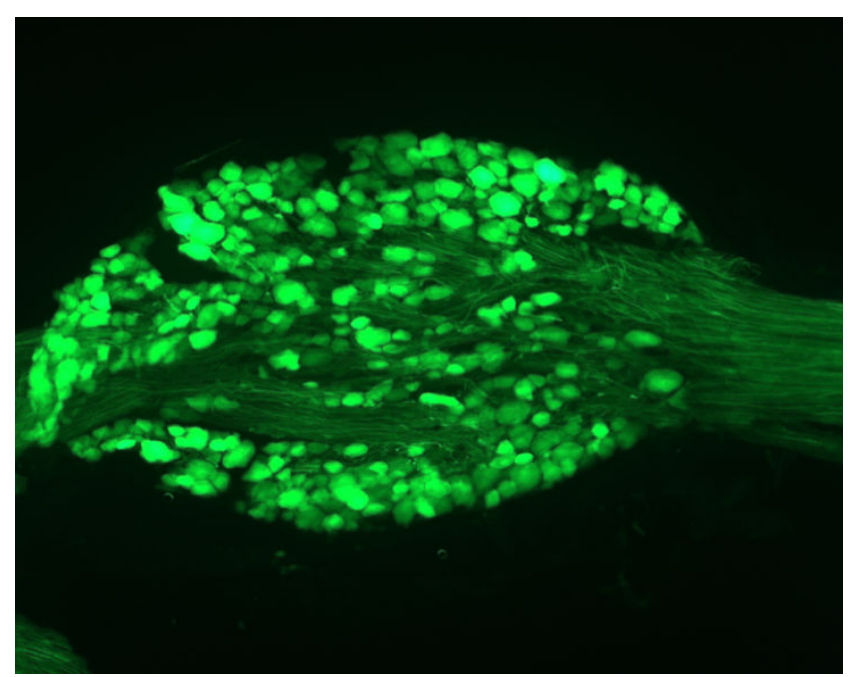

Figure 3: GFP expression in rat dorsal root ganglion. 
Citation: Jackson KL, Catalani BS, Dayton RD, Klein RL (2015) Expanded Central Nervous System Gene Transfer in Rats by Intravenous Delivery of Recombinant Adeno-Associated Virus. J Neurol Disord 3: i109. doi:10.4172/2329-6895.1000i109

Page 2 of 2

\section{References}

1. Foust KD, Nurre E, Montgomery CL, Hernandez A, Chan CM, et al. (2009) Intravascular AAV9 preferentially targets neonatal neurons and adult astrocytes. Nat Biotechnol 27: 59-65.

2. Wang DB, Dayton RD, Henning PP, Cain CD, Zhao LR, et al. (2010) Expansive gene transfer in the rat CNS rapidly produces amyotrophic lateral sclerosis relevant sequelae when TDP-43 is overexpressed. Mol Ther 18: 2064-2074.
3. Dayton RD, Gitcho MA, Orchard EA, Wilson JD, Wang DB, et al. (2013) Selective forelimb impairment in rats expressing a pathological TDP-43 25 $\mathrm{kDa}$ C-terminal fragment to mimic amyotrophic lateral sclerosis. Mol Ther 21: 1324-1334.

4. Jackson KL, Dayton RD, Orchard EA, Ju S, Ringe D, et al. (2014) Preservation of forelimb function by UPF1 gene therapy in a rat model of TDP-43-induced motor paralysis. Gene Ther. 